УДК 633.88:582.929.4

DOI https://doi.org/10.32848/agrar.innov.2021.10.14

\title{
АЛЕЛОПАТИЧНІ ОСОБЛИВОСТІ ГІСОПУ ЛІКАРСЬКОГО (HYSSOPUS OFFICINALIS L.)
}

ТКАЧОВА Є.C. - аспірант

https://orcid.org/0000-0002-4265-2934

Миколаївський національний аграрний університет

ФЕДОРЧУК М.І. - доктор сільськогосподарських наук

https://orcid.org/0000-0001-7028-0915

Миколаївський національний аграрний університет

Вступ. Основним ресурсом для вирощування сільськогосподарських культур є природна структура - ґрунт. Тому головною проблемою земельних ресурсів України та світу є деградація ґрунтів, що призводить до їх окислення та засолення, прискорення ерозійних процесів, зменшення кількості гумусу та корисних мікроорганізмів, забруднення радіонуклідами, пестицидами, важкими металами, втрати родючості та опустелювання. Загалом за останні 30 років спостерігається зменшення родючості ґрунтів та зниження вмісту гумусу $[11,10]$.

У зв'язку зі зміною клімату, що супроводжується підвищенням середньорічних температур та інтенсивними посухами, проблеми деградації ґрунтів все більше загострюються та потребують упровадження агротехнологій, що сприяють відновленню родючості ґрунтів, однією з яких є фрітомеліорація.

Фітомеліорація посилює біологічну активність ґрунту, сприяє накопиченню гумусу та покращує фізичні властивості ґрунту [5].

Останнім часом все більше досліджень спрямовані на використання ефріроолійних лікарських рослин як фрітомеліорантів, що синтезують специфічні вторинні метаболіти, в основному фенольної природи. Особливість лікарських рослин полягає у тому, що вони характеризуються наявністю певних специфічних груп з'єднань, які тією чи іншою мірою виділяються у навколишнє середовище і тим самим симбіотично впливають на ріст і розвиток сусідніх рослин, які знаходяться поруч в агрофітоценозах. До таких з'єднань відносяться глікозиди, алкалоїди, дубильні речовини, фенольні сполуки, флавоноїди, кумарини, сапоніни, хінони, смоли і бальзами, а також ефрірні олії, що являють собою складні багатокомпонентні суміші органічних сполук, головне місце серед яких належить терпеноїдам, які потрапляють у навколишнє середовище з кореневими виділеннями, змивними водами, гутацією тощо. Ефрірні олії мають високу летючість в атмосфрерному повітрі [2].

Встановлено, що рослини виділяють в ґрунт різодепозіти - кореневі ексудати, що складаються з розчинних з'єднань вуглецю, таких як цукри, амінокислоти, органічні кислоти тощо. У багаторічних рослин, окрім біомаси, у процесі культивування утворюється й мортмаса, яка також змінює властивості ґрунту шляхом формування специфрічного мікробного співтовариства, що активізує мікробіологічні процеси ґрунту. Одночасно в ґрунті можуть накопичуватися фітопатогени та токсигенні види організмів, які будуть негативно впливати на врожайність культур, що вирощуються після попередньої [7].
У зв'язку з цим метою нашого дослідження було з'ясування впливу алелопатичної активності водних екстрактів листків, стебел та квіток гісопу і ґрунту у зоні ризосфери на ріст коренів крес-салату.

Для досягнення мети були поставлені такі завдання:

- дослідити алелопатичну активність надземних органів рослини гісопу лікарського (Hyssopus officinalis L.) та ґрунту у зоні його ризосфери;

- порівняти алелопатичну активність отриманих водних екстрактів щодо тест-об'єкта;

- визначити алелопатичну активність водних екстрактів надземних органів рослини гісопу лікарського (Hyssopus officinalis L.) та ґрунту у зоні його ризоссрери щодо тест-об'єкта.

Матеріали і методи. Дослідження у модельних експериментах проводили у 2019-2021 роках на базі лабораторій Миколаївського національного аграрного університету. Алелопатичну активність у водорозчинних виділень рослин гісопу лікарського (Hyssopus officinalis L.) визначали за методикою Гродзинського [2] за допомогою біологічних тестів. Тестовою культурою були вибрані однодобові проростки крес-салату (Lepidium sativum L.). Наш вибір був зумовлений тим, що крес-салат має високу схожість насіння, тому $€$ більш чутливим до зовнішніх чинників. Для виявлення алелопатичних властивостей рослин гісопу використовували екстракти різних концентрацій з надземних органів рослини у фазі цвітіння та ґрунту, бо основним місцем проявлення алелопатичних відношень $€$ ґрунт [1]. Проби ґрунту для проведення досліджень відбирали у зоні ризосфери рослин гісопу. Для проведення досліджень використовували водний екстракт ґрунту концентрацією 1:10, 1:50, 1:100. У досліді використовували водні екстракти з листків, стебел та квіток гісопу лікарського концентрацією 1:10, 1:50, 1:100.

Насіння крес-салату пророщувалися у чашках Петрі за температури $23{ }^{\circ} \mathrm{C}$ у кількості 100 штук на кожен варіант досліду, які проводили у 3-разовій повторності. Контрольні тест-об'єкти пророщувалися за зволоження дистильованою водою. Для визначення впливу водних екстрактів різної концентрації на тест-об'єкт вимірювали довжину коренів Lepidium sativum L., приріст розраховували у відсотках до контролю методами математичної статистики [8].

$\mathrm{RI}$, response index, або індекс інгібування, що характеризує вектор та відносну величину впливу алелопатичних речовин на швидкість росту проростків крес-салату, визначали за Віл'ямсоном таким чином: 
- якщо $\mathrm{B}>\mathrm{K}$, то $\mathrm{RI}=1-(\mathrm{K} / \mathrm{B})$;

- якщо B < K, то RI = (B/K) -1 .

При цьому В - морфометричний показник зародка В досліді, К - морфометричний показник зародка в контролі.

Стимулювальний ефект відбувається за значення $\mathrm{RI}>0$, гальмувальний ефект відбувається за значення $\mathrm{RI}<0$ [12].

Результати та обговорення. У межах фрітогенного поля навкруги кожної рослини утворюється алелопатична сфрера, пов'язана з накопиченням фрізіологічно активних речовин (колінів), які виділяють рослини в навколишнє середовище. Ці речовини можуть бути, як прямими метаболітами рослини, так й ї̈ вторинними метаболітами, які вона виробляє у процесі свого росту та розвитку, а також під впливом умов навколишнього середовища. Дослідами підтверджено, що між рослинами існує алелопатичний вплив [13].

Завданням нашого досліду було визначення активності колінів в алелопатичній сфері гісопу лікарського, що дає можливість зробити висновки про цю рослину як попередника.

Отримані результати свідчать, що алелопатичний вплив гісопу лікарського на проростання насіння крес-салату змінюється залежно від віку рослини Виявлено як стимулювальну дію водних розчинів гісопу

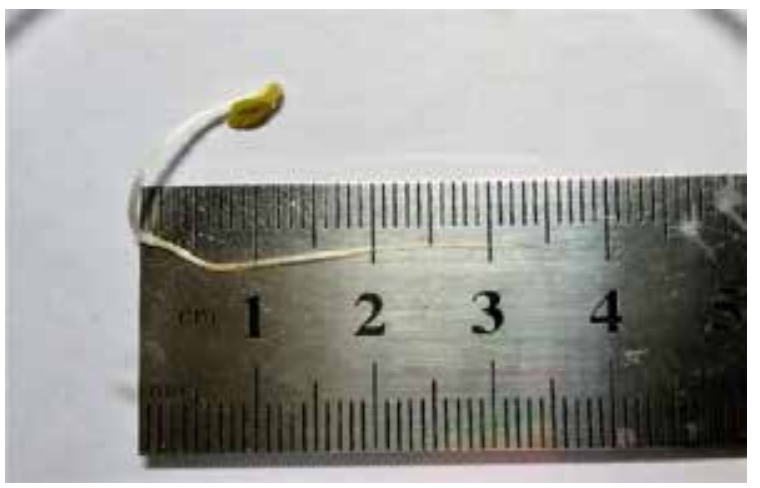

A

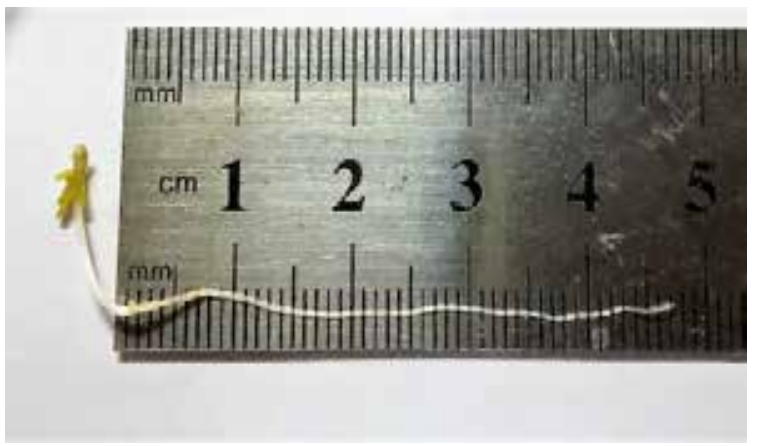

$\mathrm{C}$ на схожість насіння тест-об'єкта, так і гальмувальну дію на проростання насіння крес-салату (рис. 1).

Протягом 2019-2021 років спостерігалося накопичення колінів у ризосфрері гісопу лікарського, які мають як стимулюючий, так і інгібуючий ефект на проростання насіння крес-салату (табл. 1).

За даними таблиці 1 видно, що у 2019 році алелопатична активність ґрунту у зоні ризосфери гісопу лікарського у фазі цвітіння більш активна, вона була виражена у стимуляційному розвитку тест-об'єкта і становила $59,82 \%$ відносно контролю, а у 2020 році $56,55 \%$. Це підтверджується й величиною індексу алелопатичної активності.

Важливо відзначити, що у 2020 році стимулюючий ефрект на проростання насіння крес-салату був меншим порівняно з 2019 роком. Накопичення алелопатичних речовин у ґрунті призводить до інгібуючої дії водного розчину ґрунту зони ризосфери рослин гісопу лікарського третього року вегетації на проростання крес-салату.

Аналіз водного розчину ґрунту рослин третього року вегетації показав, що накопичилася така кількість колінів, яка мала інгібуючий вплив на проростання насіння крес-салату. Відбулося гальмування росту корінців тестоб'єкта на $11,02 \%$, що підтверджено й індексом алелопатичної активності, який становив від'ємне число, тобто менше за нуль.

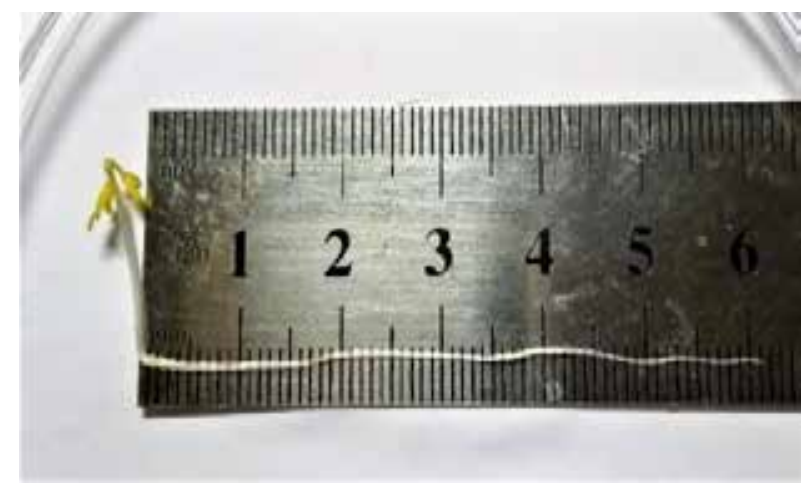

Б

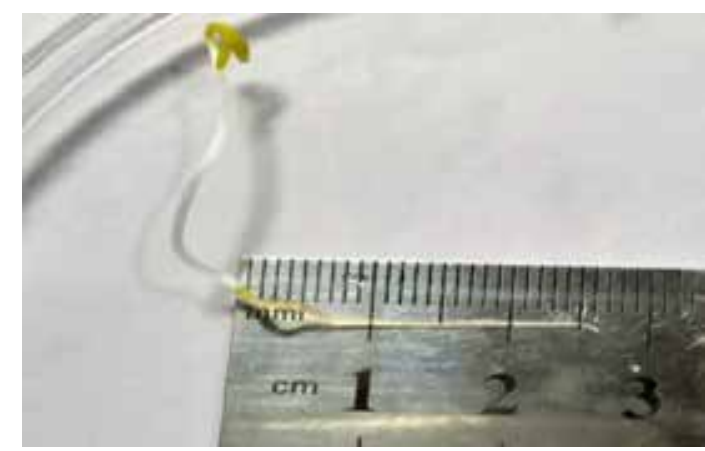

$\mathrm{D}$

Puс. 1. Вплив водного розчину ґрунту залежно від віку куща гісопу лікарського на довжину корінців насіння крес-салату (середні показники):

A - контроль, B - 1-й рік, C - 2-й рік, D - 3-й рік 
Вплив кореневих виділень рослин гісопу різних років у фазі цвітіння на приріст коренів крес-салату (розведення 1:100)

\begin{tabular}{|c|c|c|c|c|}
\hline \multirow{2}{*}{$\begin{array}{c}\text { Рік вегетації / } \\
\text { vegetation year }\end{array}$} & $\mathbf{M} \mathbf{m}$ & $\mathbf{C v} \%$ & $\begin{array}{c}\text { Алелопатична активність, \% / } \\
\text { Allelopathic activity, \% }\end{array}$ & $\begin{array}{c}\text { Індекс алелопатичної } \\
\text { активності (RI) / allelopathic } \\
\text { activity index (RI) }\end{array}$ \\
\hline Контроль/Control & $3,36 \pm 0,13$ & 39,42 & - & - \\
\hline 2019 p. & $5,37 \pm 0,15$ & 27,33 & $+59,82$ & $+0,38$ \\
\hline 2020 p. & $5,26 \pm 0,16$ & 30,45 & $+56,55$ & $+0,36$ \\
\hline 2021 p. & $2,99 \pm 0,11$ & 37,45 & $-11,02$ & $-0,11$ \\
\hline
\end{tabular}

Вплив виділень надземних органів гісопу першого року вегетації у фазі цвітіння на приріст коренів проростків крес-салату, \%

\begin{tabular}{|c|c|c|c|c|c|}
\hline $\begin{array}{c}\text { Орган / } \\
\text { plant organ }\end{array}$ & $\begin{array}{l}\text { Концентрація } \\
\text { розчину / Solution } \\
\text { concentration }\end{array}$ & $\begin{array}{c}\text { Довжина } \\
\text { кореня, мм / } \\
\text { Root length, mm }\end{array}$ & Cv, \% & $\begin{array}{c}\text { Алелопатична } \\
\text { активність, \% / } \\
\text { Allelopathic activity, \% }\end{array}$ & $\begin{array}{c}\text { Індекс алелопатичної } \\
\text { активності (RI) / Allelopathic } \\
\text { activity index (RI) }\end{array}$ \\
\hline \multirow{3}{*}{ Листок / Leaf } & $1: 100$ & $3,64 \pm 0,17$ & 46,80 & $+8,33$ & $+0,08$ \\
\hline & $1: 50$ & $3,40 \pm 0,17$ & 49,62 & $+1,19$ & $+0,01$ \\
\hline & $1: 10$ & $3,49 \pm 0,16$ & 44,80 & $+3,87$ & $+0,04$ \\
\hline \multirow{3}{*}{ Стебло / Stem } & $1: 100$ & $3,84 \pm 0,18$ & 46,44 & $+14,29$ & $+0,12$ \\
\hline & $1: 50$ & $3,79 \pm 0,15$ & 38,68 & $+12,80$ & $+0,11$ \\
\hline & $1: 10$ & $3,90 \pm 0,18$ & 46,60 & $+16,07$ & $+0,14$ \\
\hline \multirow{3}{*}{ Квітка / Flower } & $1: 100$ & $4,04 \pm 0,14$ & 34,42 & $+20,25$ & $+0,17$ \\
\hline & $1: 50$ & $4,42 \pm 0,16$ & 35,32 & $+31,55$ & $+0,24$ \\
\hline & $1: 10$ & $4,15 \pm 0,15$ & 35,69 & $+23,51$ & $+0,19$ \\
\hline \multirow{3}{*}{$\begin{array}{c}\text { Листок+стебло / } \\
\text { Leaf + stem }\end{array}$} & $1: 100$ & $4,07 \pm 0,15$ & 36,64 & $+21,13$ & $+0,17$ \\
\hline & $1: 50$ & $4,37 \pm 0,13$ & 29,49 & $+30,06$ & $+0,23$ \\
\hline & $1: 10$ & $3,45 \pm 0,13$ & 36,82 & $+2,68$ & $+0,03$ \\
\hline $\begin{array}{c}\text { Контроль / } \\
\text { Control }\end{array}$ & $\mathrm{H}_{2} \mathrm{O}$ & $3,36 \pm 0,13$ & 39,42 & - & - \\
\hline
\end{tabular}

Згідно з літературними джерелами, батьківщиною гісопу лікарського $є$ Середземномор'я та Середня Азія [4, 3].

У природному ареалі Миколаївської області гісоп лікарський не зустрічається, тому рослина є інтродукованою. Будь-яке відхилення від екологічних умов походження може викликати більш інтенсивне накопичення біологічно активних речовин в органах рослини [6].

Використання квітів гісопу в концентрації 1:50 за першого року вегетації спричиняло ріст кореневої системи крес-салату в 1,31 раза швидше порівняно з контролем. Використання комбінації «листок + стебло» призвело до незначного зменшення лінійного росту порівняно із квіткою. Всі інші комбінації не мали достовірного підтвердження. Найвища алелопатична активність (23,51-31,55\%) проявилася у разі використання водного розчину квіток рослин першого року вегетації в концентрації 1:10 - 1:50 відповідно. Зменшення концентрації до 1:100 менше стимулювало активний лінійний приріст коренів крес-салату (табл. 2).

У роки досліджень під час вивчення алелопатичного впливу віку рослин та їхніх органів на приріст коренів крес-салату нами було встановлено, що найвищий вплив на цей показник мав варіант, у якому використовувалися квітки гісопу лікарського в концентрації 1:10 рослин другого року вегетації. Ця концентрація спри- яла активним ростовим процесам кореня крес-салату, довжина якого становила 5,36 мм, що на 2,0 мм більше від контрольного варіанта. Зменшення концентрації до 1:50 - 1:100 знижувало цей показник до 4,56 -4,73 мм відповідно.

Можна відзначити використання всіх органів рослин другого року вегетації позитивно, але деякі з варіантів меншою мірою впливали на алелопатичну активність. Так, найнижчою $(13,1 \%)$ вона була у варіанті «листок + стебло» в концентрації 1:10. А найвищим $(59,52 \%)$ цей показник був у варіанті використання настою квіток в концентрації 1:50. Цей варіант мав найвищий показник індексу алелопатичної активності (RI). (табл. 3)

Використання рослин третього року вегетації призводило до різкого зменшення лінійного росту коренів крес-салату (табл. 4). До того ж водні розчини всіх варіантів концентрацій гальмували приріст коренів тестоб'єкта, тобто відбувався інгібуючий ефект.

Незважаючи на це, під час використання квіток у концентрації 1:100 та 1:50 відзначений позитивний вплив, але алелопатична активність рослин третього року вегетації значно поступається рослинам першого і другого року вегетації. Індекс алелопатичної активності у комбінації «листок + стебло» становив 0,80 (RI) проти 0,03 та 0,12 відповідно. 
Вплив виділень надземних органів гісопу другого року вегетації у фазі цвітіння на приріст коренів проростків крес-салату, \%

\begin{tabular}{|c|c|c|c|c|c|}
\hline $\begin{array}{c}\text { Орган / Plant } \\
\text { organ }\end{array}$ & \begin{tabular}{|c|} 
Концентрація \\
розчину/Solution \\
concentration \\
\end{tabular} & $\begin{array}{c}\text { Довжина } \\
\text { кореня, мм / } \\
\text { Root length, } \mathrm{mm} \\
\end{array}$ & Cv, \% & $\begin{array}{c}\text { Алелопатична } \\
\text { активність, \% / } \\
\text { Allelopathic activity, \% }\end{array}$ & \begin{tabular}{|c|} 
Індекс алелопатичної \\
активності (RI) / allelopathic \\
activity index (RI)
\end{tabular} \\
\hline \multirow{3}{*}{ Листок / Leaf } & $1: 100$ & $4,44 \pm 0,19$ & 41,92 & $+32,14$ & $+0,24$ \\
\hline & $1: 50$ & $4,54 \pm 0,17$ & 36,98 & $+35,12$ & $+0,26$ \\
\hline & $1: 10$ & $4,95 \pm 0,14$ & 28,15 & $+47,32$ & $+0,32$ \\
\hline \multirow{3}{*}{ Стебло / Stem } & $1: 100$ & $4,34 \pm 0,15$ & 34,43 & $+29,17$ & $+0,23$ \\
\hline & $1: 50$ & $4,83 \pm 0,16$ & 32,20 & $+43,85$ & $+0,30$ \\
\hline & $1: 10$ & $4,46 \pm 0,15$ & 34,33 & $+32,74$ & $+0,25$ \\
\hline \multirow{3}{*}{ Квітка / Flower } & $1: 100$ & $4,73 \pm 0,16$ & 33,39 & $+40,77$ & $+0,29$ \\
\hline & $1: 50$ & $4,56 \pm 0,16$ & 36,13 & $+35,71$ & $+0,26$ \\
\hline & $1: 10$ & $5,36 \pm 0,15$ & 28,03 & $+59,52$ & $+0,37$ \\
\hline \multirow{3}{*}{$\begin{array}{c}\text { Листок+стебло / } \\
\text { Leaf + stem }\end{array}$} & $1: 100$ & $4,73 \pm 0,18$ & 38,20 & $+40,77$ & $+0,29$ \\
\hline & $1: 50$ & $4,83 \pm 0,19$ & 39,28 & $+43,75$ & $+0,30$ \\
\hline & $1: 10$ & $3,80 \pm 0,12$ & 32,42 & $+13,10$ & $+0,12$ \\
\hline $\begin{array}{c}\text { Контроль / } \\
\text { Control }\end{array}$ & $\mathrm{H}_{2} \mathrm{O}$ & $3,36 \pm 0,13$ & 39,42 & - & - \\
\hline
\end{tabular}

Вплив виділень надземних органів гісопу третього року вегетації у фразі цвітіння

Таблиця 4 на приріст коренів проростків крес-салату, \%

\begin{tabular}{|c|c|c|c|c|c|}
\hline $\begin{array}{c}\text { Opraн / Plant } \\
\text { organ }\end{array}$ & \begin{tabular}{|c|}
$\begin{array}{c}\text { Концентрація } \\
\text { розчину / Solution } \\
\text { concentration }\end{array}$ \\
\end{tabular} & $\begin{array}{c}\begin{array}{c}\text { Довжина кореня, } \\
\text { мм / Root length, } \\
\text { mm }\end{array} \\
\end{array}$ & Cv, \% & $\begin{array}{c}\text { Алелопатична } \\
\text { активність, \% / } \\
\text { Allelopathic activity, \% } \\
\end{array}$ & $\begin{array}{c}\text { Індекс алелопатичної } \\
\text { активності (RI) / Allelopathic } \\
\text { activity index (RI) }\end{array}$ \\
\hline \multirow{3}{*}{ Листок / Leaf } & $1: 100$ & $2,60 \pm 0,07$ & 26,64 & $-22,62$ & $-0,23$ \\
\hline & $1: 50$ & $2,51 \pm 0,08$ & 31,36 & $-25,30$ & $-0,25$ \\
\hline & $1: 10$ & $1,02 \pm 0,05$ & 52,80 & $-69,64$ & $-0,70$ \\
\hline \multirow{3}{*}{ Стебло / Stem } & $1: 100$ & $2,73 \pm 0,09$ & 34,26 & $-18,75$ & $-0,19$ \\
\hline & $1: 50$ & $2,59 \pm 0,09$ & 35,14 & $-22,92$ & $-0,23$ \\
\hline & $1: 10$ & $1,46 \pm 0,07$ & 45,70 & $-56,55$ & $-0,57$ \\
\hline \multirow{3}{*}{ Квітка / Flower } & $1: 100$ & $2,96 \pm 0,11$ & 36,04 & $-11,90$ & $-0,12$ \\
\hline & $1: 50$ & $2,81 \pm 0,10$ & 36,44 & $-16,37$ & $-0,16$ \\
\hline & $1: 10$ & $1,85 \pm 0,06$ & 30,19 & $-44,90$ & $-0,45$ \\
\hline \multirow{3}{*}{$\begin{array}{c}\text { Листок+стебло / } \\
\text { Leaf + stem }\end{array}$} & $1: 100$ & $1,39 \pm 0,05$ & 33,94 & $-58,63$ & $-0,59$ \\
\hline & $1: 50$ & $1,12 \pm 0,05$ & 45,10 & $-66,67$ & $-0,67$ \\
\hline & $1: 10$ & $0,68 \pm 0,03$ & 46,05 & $-79,76$ & $-0,80$ \\
\hline $\begin{array}{c}\text { Контроль / } \\
\text { Control } \\
\end{array}$ & $\mathrm{H}_{2} \mathrm{O}$ & $3,36 \pm 0,13$ & 39,42 & - & - \\
\hline
\end{tabular}

Висновки. Таким чином, усі частини рослин гісопу лікарського мають алелопатичний вплив на лінійний ріст кореневої системи крес-салату. У перші два роки досліджень спостерігався стимулювальний ефект водних розчинів ґрунту кореневої зони та надземних органів рослин гісопу незалежно від їх концентрацій. Нами встановлено, що найвищу алелопатичну активність мав варіант із використанням квіток гісопу в концентрації 1:10 рослин другого року вегетації. Водні розчини ґрунту кореневої зони гісопу лікарського та його надземних органів третього року вегетації показали інгібуючий ефект на лінійний приріст коренів крес-салату. Найбільшим він був у варіанті «листок + стебло» за концентрації водного розчину 1:10. Тому для того, щоб рекомендувати гісоп лікарський як добрий попередник для вирощування сільськогосподарських культур. потрібні додаткові дослідження.

\section{СПИСОК ВИКОРИСТАНОÏ ЛІТЕРАТУРИ:}

1. Гродзинский А.М. Аллелопатическое почвоутомление : монография. Киев : Наукова думка, 1979. $248 \mathrm{c}$.

2. Гродзинський А.М. Основи хімічної взаємодії рослин : монография. Київ : Наукова думка, 1973. 207 с.

3. Жарінов В.І., Остапенко А.І. Вирощування лікарських, ефріроолійних, пряносмакових рослин : навчальний посібник. Київ : Вища школа, 1994. 234 с.

4. Машанов В.И., Покровский А.А. Пряноароматические растения. Москва : Агропромиздат, 1991. 287 с.

5. Постников Д.А., Курило А.А. Фитомелиоративное влияние горчицы белой и сафлора на содержание фосфора, калия и микробиологическую активность дерново-подзолистой почвы. Достижения науки и техники АПК. 2010. Вип. 2. С. 15-20.

6. Райс Э. Аллелопатия. Москва : Мир, 1978. 392 с. 
7. Свистова И.Д., Кувшинова Н.М., Стекольников К.Е., Назаренко Н.Н. Лекарственные растения как фитомелиоранты на черноземе выщелоченном. Научные ведомости. Серия Естественные науки. 2016. № 4 (225). Вип. 34. С 32-38.

8. Шмидт В.М. Математические методы в ботанике. Ленинград : Ленинградский университет, 1984. 288 с.

9. More than $40 \%$ of all agricultural land in Ukraine may lose fertility, according to research. Ecoaction. 2021. URL: $\quad$ https://en.ecoaction.org.ua/more-than-40-agland-may-lose.html

10. Ukraine. Knowledge Hub. 2018. URL: https:// knowledge.unccd.int/home/country-information/ countries-having-set-voluntary-Idn-targets/ukraine

11. Bruce Williamson G., Richardson D. Bioassays for allelopathy: Measuring treatment responses with independent controls. Journal of Chemical Ecology. 1988. Vol. 14, no. 1. P 181-187. URL: https://doi. org/10.1007/bf01022540

12. Zorikova O., Manyakhin A., Koldaev V., Moiseenko L., \& Litvinova E. Allelopathic activity of patrinia scabiosifolia and Patrinia rupestris. Biomedical and Pharmacology Journal. 2017. Vol. 10, no. 02. 651-658 pp. https://doi. org/10.13005/bpj/1152

\section{REFERENCES:}

1. Grodzinsky, A.M. (1979). Allelopaticheskoye pochvoutomleniye [Allelopathic soil fatigue]. Kiyev: Naukova dumka, 248 [in Russian].

2. Grodzinsky, A.M. (1973). Osnovy khimichnoyi vzayemodiyi roslyn [Fundamentals of chemical interaction of plants]. Kyiv: Naukova dumka, 207 [in Ukrainian].

3. Zharinov, V.I., \& Ostapenko, A.I. (1994). Vyroshchuvannya likars'kykh, efirooliynykh, pryanosmakovykh roslyn [Cultivation of medicinal, essential oil, and spicy-flavored plants]. Kiev: Vysshaya Shkola, 234 [in Ukrainian].

4. Mashanov, V.I., \& Pokrovsky, A.A. (1991). Pryanoaromaticheskiye rasteniya [Spicy-aromatic plants]. Moscow: Agropromizdat, 287 [in Russian].

5. Postnikov, D.A., \& Kurilo, A.A. (2010). Fitomeliorativnoye vliyaniye gorchitsy beloy i saflora na soderzhaniye fosfora, kaliya i mikrobiologicheskuyu aktivnost' dernovo-podzolistoy pochvy [Phytomeliorative effect of white mustard and safflower on the content of phosphorus, potassium and microbiological activity of sod-podzolic soil]. Dostizheniya nauki i tekhniki APK - Achievements of science and technology of the agro-industrial complex, 2, 15-20 [in Russian].

6. Rice, E. (1978). Allelopatiya [Allelopathy]. Moscow: Mir, 392 [in Russian].

7. Svistova, I.D., Kuvshinova, N.M., Stekolnikov, K.E., \& Nazarenko, N.N. (2016). Lekarstvennyye rasteniya kak fitomelioranty na chernozeme vyshchelochennom [Medicinal plants as phytomeliorants on leached chernozem]. Nauchnyye vedomosti. Seriya Yestestvennyye nauki - Scientific Bulletin. Natural Sciences Series, 4 (225), 34, 32-38 [in Russian].

8. Schmidt, V.M. (1984). Matematicheskiye metody $v$ botanike [Mathematical methods in botany]. Leningrad: Leningrad University, 288 [in Russian].

9. More than $40 \%$ of all agricultural land in Ukraine may lose fertility, according to research. (2021, 22 April). Ecoaction. URL: https://en.ecoaction.org.ua/more-than40-ag-land-may-lose.html
10. Ukraine. knowledge hub. (2018). URL: https:// knowledge.unccd.int/home/country-information/ countries-having-set-voluntary-Idn-targets/ukraine

11. Bruce Williamson, G., \& Richardson, D. (1988). Bioassays for allelopathy: Measuring treatment responses with independent controls. Journal of Chemical Ecology, Vol. 14, no. 1. P. 181-187. URL: https://doi.org/10.1007/bf01022540

12. Zorikova, O., Manyakhin, A., Koldaev, V., Moiseenko, L., \& Litvinova, E. (2017). Allelopathic activity of patrinia scabiosifolia and Patrinia rupestris. Biomedical and Pharmacology Journal, Vol. 10, no. 02, 651-658 pp. https://doi.org/10.13005/bpj/1152

Ткачова Є.С., Федорчук М.І. Алелопатичні особливості ricoпу лікарського (Hyssopus officinalis L.)

Мета. З'ясувати вплив алелопатичної активності водних екстрактів листків, стебел, квіток і Ґрунту у зоні ризосфрери рослин гісопу лікарського (Hyssopus officinalis L.) на ріст коренів крес-салату (Lepidium sativum L.). Методи. Була досліджена алелопатична активність у водорозчинних виділень рослин гісопу лікарського (Hyssopus officinalis L.). Закладка дослідів, обліки та спостереження виконувалися за класичними методиками А.М. Гродзинського (1973) та В. М. Шмидта (1984). Індекс інгібування розраховували за методикою Віл'ямсона (1988). Результати. З'ясовано, що найбільша алелопатична активність ґрунту у кореневій зоні гісопу була досягнута у рослин першого року вегетації $(59,82 \%)$. Найвища алелопатична активність рослин гісопу першого року вегетації у разі використання водного розчину квіток проявлялася у концентрації 1:50 та становила $31,55 \%$. При цьому довжина кореня крес-салату становила 4,42 мм. Найвищий стимулювальний ефрект на лінійний приріст кореня крес-салату було досягнуто у варіанті з використанням водного екстракту квітів рослин гісопу другого року вегетації в концентрації 1:10. Довжина кореня тест-об'єкта становила 5,36 мм. Найбільший алелопатичний вплив інгібуючого характеру відбувся 3 використанням водного екстракту в концентрації 1:10 у варіанті «лист + стебло» рослин третього року вегетації. Довжина кореня крес-салату становила 0,68 мм. Висновки. Показана залежність алелопатичної активності гісопу лікарського від віку та концентрації водних екстрактів листків, стебел та квіток і ґрунту у зоні ризосфрери рослини. Встановлено алелопатичний вплив водних екстрактів кореневих виділень та надземних органів рослин гісопу лікарського у фразі цвітіння у концентраціях 1:100, 1:50 та 1:10 на лінійний ріст коренів крес-салату. Найбільшим він був у варіанті з використанням квіток гісопу в концентрації водного розчину 1:10 рослин другого року вегетації. На відміну від першого та другого років вегетації гісопу лікарського, використання водних розчинів рослин третього року вегетації мало інгібуючий вплив на лінійний приріст коренів крес-салату.

Ключові слова: гісоп лікарський, фраза цвітіння, алелопатична активність, індекс алелопатичної активності, водні екстракти.

Tkachova Y.S., Fedorchuk M.I. Allelopathic features of common hyssop (Hyssopus officinalis L.)

Aim. To find out the influence of allelopathic activity of aqueous extracts of leaves, stems, flowers and soil in the rhizosphere zone of plants of common 
hyssop (Hyssopus officinalis L.) on the growth of watercress roots (Lepidium sativum L.). Methods. Allelopathic activity was studied in water-soluble secretions of common hyssop plants (Hyssopus officinalis L.). The establishment of experiments, records and observations were performed according to the classical methods of A. M. Grodzinsky (1973) and V. M. Schmidt (1984). The inhibition index was calculated using the Williamson method (1988). Results. It was found that the greatest allelopathic activity of the soil in the root zone of hyssop was achieved in plants of the first year of vegetation and amounted up to $59.82 \%$. The highest allelopathic activity of hyssop plants of the first year of vegetation when using an aqueous solution of flowers was manifested at a concentration of 1:50 and amounted up to $31.55 \%$. At the same time, the length of the watercress roots was $4.42 \mathrm{~mm}$. The highest stimulating effect on the linear growth of watercress roots was achieved in the variant using an aqueous extract of hyssop flowers of the second year of vegetation at a concentration of 1:10. The root length of the test object was $5.36 \mathrm{~mm}$. The greatest allelopathic effect of an inhibitory nature occurred with the use of an aqueous extract at a concentration of 1:10 in the leaf + stem variant of plants of the third year of vegetation. The length of the watercress roots was $0.68 \mathrm{~mm}$. Conclusions. It was shown the dependence of the allelopathic activity of common hyssop (Hyssop officinalis L.) on the age and concentration of aqueous extracts of leaves, stems and flowers and soil in the rhizosphere zone of the plant. It was established the allelopathic effect of water extracts of root secretions and aboveground organs of hyssop plants (Hyssop officinalis L.) in the flowering phase at concentrations of 1:100, 1:50 and 1:10 on the linear growth of watercress roots. It was the largest in the variant using hyssop flowers at a concentration of an aqueous solution of 1:10 of plants of the second year of vegetation. In contrast to the first and second years of vegetation of hyssop (Hyssop officinalis L.), the use of aqueous solutions of plants of the third year of vegetation had an inhibitory effect on the linear growth of watercress roots.

Key words: Hyssop officinalis L., flowering phase, allelopathic activity, allelopathic activity index, water extracts. 